\section{Øyeblikkelig hjelp for små pasienter}

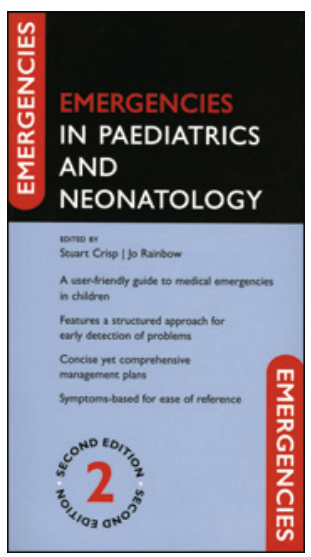

Stuart Crisp, Jo Rainbow, red.

Emergencies in paediatrics and neonatology

2. utg. 547 s, tab, ill. Oxford: Oxford University Press, 2013. Pris GBP 28

ISBN 978-0-19-960553-8

Denne boken er, som liknende utgivelser fra Oxford, et hendig oppslagsverk til bruk i den kliniske hverdagen, og i dette tilfellet i akutte situasjoner. Således er målgruppen turnusleger og leger i spesialisering innenfor pediatri, men boken vil også være nyttig for ferdige spesialister. Den vil også være et flott arbeidsverktøy for allmennleger med interesse for faget. Forfatterne har samlet sett en bred faglig bakgrunn, og arbeidsstedene er stort sett Australia eller Oxford i England.

Tanken er at dette skal være en brukervennlig håndbok i øyeblikkelig hjelp-situasjoner innenfor pediatri og nyfødtmedisin. Den har et praktisk lommeformat, inneholder enkle og oversiktlige flytdiagrammer, og de viktigste momentene er innrammet med rødt innenfor vært tema.

Teksten er symptombasert og delt opp i akutte tilstander innenfor nyfødtmedisin og generell pediatri, inkludert generell kirurgi, ortopedi, gynekologi, øre-nese-hals og øye. Leseren får også vite hva som er viktig å ha i mente ved ungdomsmedisin innenfor hvert tema. I en egen oversiktlig del går forfatterne gjennom praktiske prosedyrer som intubering og innleggelse av navlearteriekateter, med dertil passende og gode illustrasjoner. Avslutningsvis er det noen nyttige tilleggskapitler om biokjemiske normalverdier, væskeog elektrolyttforstyrrelser, motoriske milepæler og normalverdier for de fleste vitale parametre.

Nyfødtdelen er rett og slett for sparsom med kun 30 sider, men de viktigste tilstandene er dekket. Denne delen inneholder ikke tilstrekkelig informasjon til bruk i den pediatriske hverdagen. Men de resterende 500 sidene gjør opp for denne åpenbare mangelen. Den symptombaserte inndelingen er lett å finne frem i og gir en god oversikt over årsaker og viktige nøkkelelementer i anamnesen og $\mathrm{i}$ behandlingen. Medisindosene er inkludert i teksten og hentet fra British National Formulary for children (BNF for children). Dette gjør at det til tider vil være behandlingsforslag som ikke er førstevalget ifølge norske retningslinjer, som kefalosporiner til ukompliserte urinveisinfeksjoner. Boken er likevel helt oppdatert på for eksempel bronkiolittbehandling. Flytskjemaene og de oversiktlige rammene bidrar til at den blir et godt arbeidsverktøy.

Siden enkelte behandlingsforslag ikke er helt i tråd med norske retningslinjer, vil utgivelsen kun være et - utmerket - supplement til den eksisterende akuttveilederen i pediatri utgitt av Norsk barnelegeforening. Jeg anbefaler den hovedsakelig på grunn av den symptombaserte tilnærmingen og de flotte tilleggskapitlene.

\section{Gammelt nytt i historisk artikkelsamling}

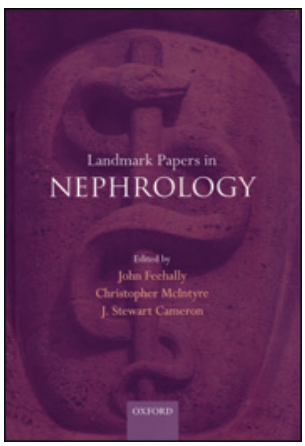

John Feehally, Christopher Mclntyre,

J. Stewart Cameron, red.

Landmark papers in nephrology

452 sider. Oxford: Oxford University Press,

2013. Pris GBP 60

ISBN 978-0-19-969925-4

Redaktørenes hensikt er å peke på viktige studier som har utviklet nefrologi til det faget er i dag. 26 forfattere har i 20 kapitler beskrevet om lag 200 studier som har vært sentrale. Forfatterne er alle fremtredende nyreleger, de aller fleste engelske som redaktørene selv. Dette er altså ikke en lærebok.

Artiklene spenner over alle deler av nefrologi fra anatomi og fysiologi til akutt og kronisk nyresykdom, dialyse og transplantasjon, epidemiologi, sammenheng mellom hjerte- og nyresykdom og behandling. Emnene blir kort oppsummert og kommentert i hvert kapittel.

Det begynner i 1827 med Richard Bright som publiserte 24 detaljerte pasienthistorier med nyresykdommer. Nyrene til avdøde pasienter ble grundig undersøkt. Bright beskrev med detaljerte illustrasjoner tre typer syke nyrer: den hissige, svulne og røde nyren, den bleke, forstørrede nyren og den harde og granulære nyren.

Selv om den kirurgiske teknikken var kjent, var det økende kunnskap om forkastelsesreaksjoner og immunologiske prinsipper som muliggjorde nyretransplantasjon i dagens omfang. Det er få nordiske referanser i boken, og artikkelen om humane transplantasjonsantigener av Kissmeyer-Nielsen og Thorsby i Transplantation Review i 1970 er den eneste vi har klart å finne med norsk tilknytning.

Noe av det største som har skjedd for kronisk nyresyke pasienter utover mulighet for nyreerstattende behandling som dialyse og nyretransplantasjon, er muligheten til å behandle renal anemi med erytropoietin. De siste 20 årene er dette rutinemessig blitt gitt til norske nyrepasienter. Nyreleger oppfattet det som et enormt fremskritt. Behandlingen av diabetesnefropati har hindret mange $\mathrm{i}$ å ende i dialyse. Arbeidene til dansker som Carl Erik Mogensen og Hans Parving om god blodtrykksbehandling for å hindre progresjon av nyreskade, er velkjent av norske leger og har vært fulgt $i$ allmennpraksis de siste 15-20 årene.

Det siste kapitlet omhandler pasientperspektivet og livskvaliteten hos nyrepasienter. At dialysepasienter har sterkt redusert livskvalitet har vært lite påaktet, til tross for at leger og annet helsepersonell møter disse pasientene oftest tre ganger ukentlig gjennom flere år. I en av artiklene blir vi påminnet om rutinemessig å undersøke plager og symptomer som pasienten har, og å gjøre noe med det. Artiklene som omtales, er stort sett fra etter 2005, noe som også forteller noe om hvordan pasientperspektivet er blitt ignorert i flere år.

Vi har hatt stor glede av å bla igjennom denne boken og å lese utdrag og oppsummering av artikler som har vært, og er, viktige i nefrologien. Samtidig er dette en bok som nok er for den spesielt interesserte nyrelegen, og det er vanskelig å anbefale den til andre enn historisk interesserte.

Ingrid Os og Aud-Eldrid Stenehjem

Nyremedisinsk avdeling

Oslo universitetssykehus, Ullevål 